\title{
Zooplankton body-size structure and biomass in tropical floodplain lakes: relationship with planktivorous fishes
}

\author{
Estrutura de tamanho do corpo e biomassa do zooplâncton em lagos tropicais de \\ planície de inundação: relaçôes com peixes planctívoros
}

Claudia Costa Bonecker ${ }^{1}$, Fábio de Azevedo ${ }^{2}$ and Nadson Ressyé Simôes ${ }^{1}$
${ }^{1}$ Núcleo de Pesquisas em Limnologia e Aquicultura - Nupélia, Universidade Estadual de Maringá - UEM, Av. Colombo, 5790 - Bloco H-90, Maringá, PR, Brazil e-mail: bonecker@nupelia.uem.br; nadsonressye@yahoo.com.br
${ }^{2}$ Faculdade Estadual de Educação, Ciências e Letras de Paranavaí - FAFIPA, Brazil e-mail: fabioazeve@yahoo.com.br

\begin{abstract}
Aim: This study evaluated whether the size structure of the zooplankton community, as analyzed from density and biomass, would be influenced by bottom-up and/or top-down mechanisms in isolated lakes from the Upper Paraná River floodplain during dry and rainy periods. Methods: zooplankton individuals were classified as: smaller-sized $(<300 \mu \mathrm{m})$, intermediate-sized $(301$ to $600 \mu \mathrm{m})$ and larger-sized (greater than $601 \mu \mathrm{m}$ ). Fish abundance was indexed by the capture per unit effort (CPUE; number of individuals. $100 \mathrm{~m}^{-2}$ ). Productivity was measured as chlorophyll- $a$. Results: The size structure of the community did not show significant relationship with chlorophyll-a concentration $(p>0.05)$, but it was associated to the increase in fish density during the dry season. The percentage of individuals with intermediate sizes (301 to $600 \mu \mathrm{m}$ ), in both biomass and density, was positively related to the fish density $\left(\mathrm{R}^{2}=0.78\right.$ for biomass, $\mathrm{p}<0.001 ; \mathrm{R}^{2}=0.58$ for density, $\mathrm{p}=0.02$ ), indicating an increase numerical and mass of this size class with fish density. The percentage of larger-sized individuals $(>600 \mu \mathrm{m})$, in both biomass $\left(\mathrm{R}^{2}=0.86, \mathrm{p}<0.001\right)$ and density $\left(\mathrm{R}^{2}=0.69, \mathrm{p}=0.02\right)$ was negatively associated to the fish density, reflecting a decrease of this size class with the increase of fish in the environment. Conclusions: This can implicate a direct and negative effect of the predation on larger-sized individuals, as well as indirect and positive effect on the intermediate-sized individuals, but it occurred only on dry season. Thus, different mechanisms act on the size structure of the zooplankton community between dry and rainy season.
\end{abstract}

Keywords: predation, seasonal variation, fishes, shallow lakes, zooplankton body length.

Resumo: Objetivo: Este estudo avaliou se a estrutura de tamanho da comunidade zooplanctônica, analisada a partir da densidade e da biomassa, seria influenciada por processos ascendentes e/ou descendentes em lagos da planície de inundação do Alto Rio Paraná durante um período seco e outro chuvoso. Métodos: o zooplâncton foi classificado em: pequeno porte $(<300 \mu \mathrm{m})$, porte intermediário $(301 \mathrm{a} 600 \mu \mathrm{m})$ e maior porte (maior que $601 \mu \mathrm{m}$ ). Abundância de peixes foi estimada em captura por unidade de esforço (CPUE; número de indivíduos. $100 \mathrm{~m}^{-2}$ ). Produtividade foi definida como a concentração de clorofila- $a$. Resultados: A estrutura de tamanho da comunidade não apresentou relaçóes significantes com a concentraçáo de clorofila- $a(\mathrm{p}>0,05)$, mas ela foi associada com o aumento da densidade de peixes no período seco. O percentual de indivíduos com tamanhos intermediários (301-600 mm), tanto em biomassa quanto em densidade, foi positivamente relacionado com a densidade de peixes $\left(\mathrm{R}^{2}=0,78\right.$ para biomassa, $\mathrm{p}<0,001 ; \mathrm{R}^{2}=0,58$ para densidade, $\left.\mathrm{p}=0,02\right)$, indicando um aumento numérico e em massa dessa classe de tamanho com o aumento da densidade de peixes. A percentagem de indivíduos de maior porte $(>600 \mathrm{~mm})$, tanto em biomassa $\left(\mathrm{R}^{2}=0,86\right.$, $p<0,001)$ quanto em densidade $\left(R^{2}=0,69, p=0,02\right)$, esteve negativamente associado com a densidade de peixes, refletindo uma diminuição desta classe de tamanho com o aumento da densidade de peixes no ambiente. Conclusóes: Isto pode implicar um efeito direto e negativo da predação sobre indivíduos de maior porte, bem como efeito indireto e positivo sobre os indivíduos de pequeno porte. No entanto, esta relação foi observada apenas no período seco. Assim, diferentes mecanismos atuam sobre a estrutura de tamanho da comunidade de zooplâncton entre os períodos analisados.

Palavras-chave: predação, variação sazonal, peixes, lagos rasos, comprimento do corpo do zooplâncton. 


\section{Introduction}

Brooks and Dodson (1965) showed that interactions of competition and predation influenced the structure of the zooplankton community in different lakes in the USA. The authors formulated the size-efficiency hypothesis, which indicates that filter-feeding zooplankton compete for a similar size of food $(1-15 \mu \mathrm{m})$ and that the larger zooplankton filter particles more efficiently than the small zooplankton. But, when the predation pressure by fish is intense, larger zooplankton will be removed of the community and small zooplankton will dominate. On contrary, larger zooplankton will dominate due to their greater ability of filter-feeding overcoming competitively small ones. Dodson (1974) tested the size-efficiency hypothesis, showing that the larger zooplankton does not always exclude the smaller ones through competition for food. The author suggested an alternative hypothesis to extend the understanding of the importance of size-selective predators in order to include invertebrates selecting small prey. If the vertebrate predators are present, small zooplankton and invertebrate predators coexist. In the opposite, the latter predators coexist with large zooplankton.

This context suggests that large zooplankton should be a better competitor when resources become limiting due to their ability to use large and small particles and to survive at lower food levels, even if the partitioning of food resources among different sizes of zooplankton reduces competition between them: small zooplankton (rotifers and small cladocerans) ate fine particles $(1-5 \mu \mathrm{m})$, whereas larger zooplankton (larger cladocerans and copepods) consumed larger particles $(<5-15 \mu \mathrm{m})$ (Gliwicz, 1969).

However, Bogdan and Gilbert (1984) stated that there is no general relationship between zooplankton body length and the ability to ingest very small bacterial and algal cells. The efficiency rate of Crustacea, for example, on ultraplankton (planktonic organisms lesser than 2 micrometers in size) appears to be also correlated with the structural characteristics of the feeding appendages rather than with body size (Elmoor-Loureiro, 2005; Hart and Bychek, 2011). Body length certainly influences the maximal particle size a species can ingest, but it has little influence on the ingestion of smaller particles (Brooks and Dodson, 1965).

Body size is one of the most important parameters that determine the ecological and physiological characteristics of an organism (Peters, 1983). It also can reflect the competitive abilities of all organisms within a population and thus reflect the question of niche selection, predation relationship and the coexistence of similar species (Lampert and Sommer, 1997; Chase et al., 2002). Current studies point out that the predation on zooplankton species, especially by fish, has an important effect on the temporal variation of the community body size, resulting in an increase of small zooplankton dominance (Horn, 2003; Hambright, 2008). Nevertheless, this change in the size spectrum of the community also depends on the temporal dynamics from the involved populations, such as life cycle (Winder et al., 2003); and, on the smaller size of zooplankton species from tropical regions (Fernando, 1994); or, thermal influences (Hart and Bychek, 2011).

In this way, if the predation pressure is constant in tropical environments, the assessments concerning the size-selective predators hypothesis on the zooplankton community, in natural conditions, would be limited because the smallsized species numerically predominate in the community over time, since the zooplankton's predators be present. Thus, we tested the sizeselective predators hypothesis, and if size spectrum of the zooplankton community is associated with availability food. Therefore, the present study evaluated whether the organization of size structure in the zooplankton community would be influenced by bottom-up and/or top-down mechanisms in isolated lakes from the Upper Paraná River floodplain, during both a rainy and a dry periods. This implies that the size-efficiency hypothesis may also explain the community structure, and may further contribute to the differentiation of the size spectrum from the community between tropical and temperate lakes.

\section{Material and Methods}

\subsection{Study area}

The shallow lakes sampled (Capivara-A, Aurélio-B, Clara-C, Jacaré-D, Genipapo-E, Osmar-F, Traíra-G and Pousada-H) are located in the Upper Paraná River floodplain in the Paraná and Mato do Grosso do Sul States, Brazil (Figure 1). They have mean depth ranging 0.96 to $3.60 \mathrm{~m}$ and surface area ranging 0.006 to 7.20 ha (Table 1 ). The samples were carried out during the dry (August 2000) and rainy (February 2001) periods in order to verify if the results depend on the period. Maximum hydrometric level achieved 3.46 and $4.14 \mathrm{~m}$, dry and rainy, respectively. 


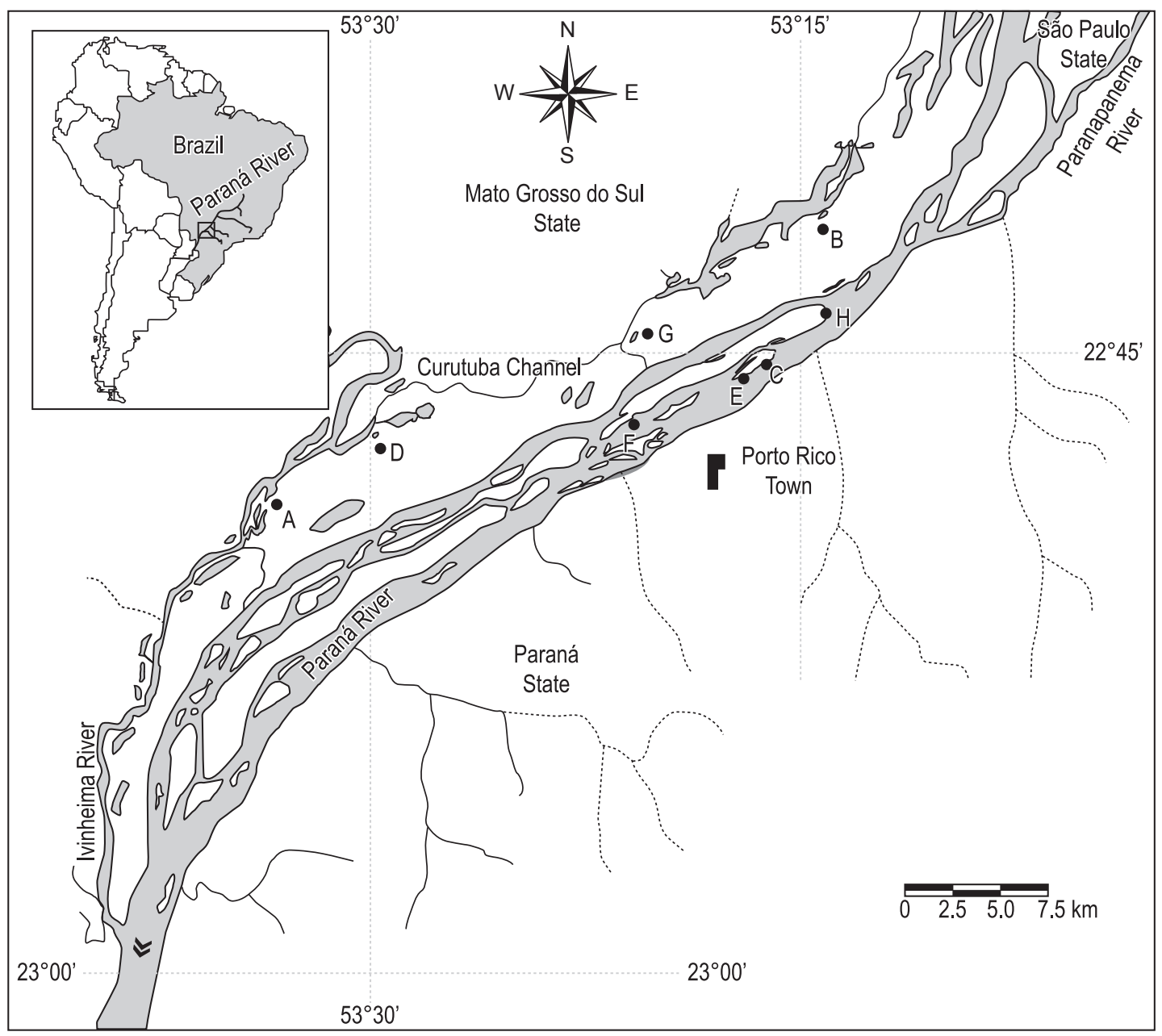

- Sampling lakes $\approx$ Direction of flow

Figure 1. Study area and sampling lakes in the Upper Paraná River Floodplain (Capivara-A, Aurélio-B, Clara-C, Jacaré-D, Genipapo-E, Osmar-F, Traíra-G and Pousada-H).

Table 1. Location and general characterization of the lakes' size in the Upper Paraná floodplain.

\begin{tabular}{|c|c|c|c|}
\hline & $\begin{array}{c}\text { Mean } \\
\text { depth }(m)\end{array}$ & $\begin{array}{l}\text { Area } \\
\text { (ha) }\end{array}$ & $\begin{array}{l}\text { Geographic } \\
\text { coordinates }\end{array}$ \\
\hline Aurélio - B & 1.95 & 0.43 & $\begin{array}{l}22^{\circ} 41^{\prime} 34.68 " \mathrm{~S} ; \\
53^{\circ} 13^{\prime} 50.58^{\prime \prime} \mathrm{W}\end{array}$ \\
\hline Capivara - A & 3.60 & 7.20 & $\begin{array}{l}22^{\circ} 47^{\prime} 56.52^{\prime \prime} \mathrm{S} ; \\
53^{\circ} 32^{\prime} 5.4^{\prime \prime} \mathrm{W}\end{array}$ \\
\hline Clara - C & 1.20 & 0.90 & $\begin{array}{l}22^{\circ} 45^{\prime} 17.52^{\prime \prime} \mathrm{S} ; \\
53^{\circ} 15^{\prime} 28.62 \text { ' W }\end{array}$ \\
\hline Genipapo - E & 0.96 & 0.06 & $\begin{array}{l}22^{\circ} 45^{\prime} 33.24^{\prime \prime} \mathrm{S} ; \\
53^{\circ} 16^{\prime} 5.94^{\prime \prime} \mathrm{W}\end{array}$ \\
\hline Jacaré - D & 2.14 & 6.96 & $\begin{array}{l}22^{\circ} 47^{\prime} 2.04^{\prime \prime} \mathrm{S} ; \\
53^{\circ} 29^{\prime} 49.08^{\prime \prime} \mathrm{W}\end{array}$ \\
\hline Osmar - F & 1.10 & 0.006 & $\begin{array}{l}22^{\circ} 46^{\prime} 26.64^{\prime \prime} \mathrm{S} ; \\
53^{\circ} 19^{\prime} 56.16^{\prime \prime}\end{array}$ \\
\hline Pousada - H & 2.30 & 3.80 & $\begin{array}{l}22^{\circ} 42^{\prime} 1.14^{\prime \prime} \mathrm{S} ; \\
53^{\circ} 15^{\prime} 23.52^{\prime \prime} \mathrm{W}\end{array}$ \\
\hline Traíra - G & 2.10 & 0.47 & $\begin{array}{l}22^{\circ} 44^{\prime} 45.6^{\prime \prime} \mathrm{S} ; \\
53^{\circ} 20^{\prime} 21.66^{\prime \prime} \mathrm{W}\end{array}$ \\
\hline
\end{tabular}

\subsection{Field sampling}

Water samples were collected with a van Dorn bottle from the subsurface in the pelagic region of each lake in order to analyze limnological features of water. Water temperature, concentration of dissolved oxygen (YSI oximeter), $\mathrm{pH}$, electric conductivity (DIGIMED potentiometer), total alkalinity (Carmouze, 1994), water transparency (turbidimeter) was measured in situ. Sub-samplings of water were transported to laboratory for analyses of chlorophyll- $a$ and nutrients.

Zooplankton samples were undertaken in the limnetic region from each lake at the subsurface (between 0.5 and $1.5 \mathrm{~m}$ ) in the morning, in order to minimize possibility of diurnal vertical migration (even the lakes were shallow), using a motorized pump and a plankton net $(68 \mu \mathrm{m})$ filtering $600 \mathrm{~L}$ of water per sample, and were 
preserved in formaldehyde at $4 \%$ buffered with calcium carbonate. Samples were always obtained using a boat moving at constant speed to prevent a biased sampling.

Fish were captured on September 2000 and March 2001 using $20 \mathrm{~m}$ seining nets (internal mesh of $0.5 \mathrm{~cm}$ opposite knots) operated during the day in littoral zones. The species abundances in every sample were indexed by the capture per unit effort (CPUE; number of individuals. $100 \mathrm{~m}^{-2}$ ).

\section{Laboratory Analyses}

Water samples for chlorophyll-a concentration were stored in an ice chest, and then they were filtered through GF 52-C 130 membranes $(<10$ hours after sampling) and immediately frozen $\left(-20{ }^{\circ} \mathrm{C}\right)$ for further analyses according Golterman et al. (1978). The ions nitrate, nitrite, ammonium and reactive dissolved phosphate were measured in a spectrophotometer, according to Bergamin et al. (1978), Mackereth et al. (1978) and Golterman et al. (1978). Some studies have used chlorophyll-a concentration as surrogate to primary productivity (Declerck et al., 2007; Thackeray, 2007).

Zooplankton abundance was estimated from counting $2 \mathrm{~mL}$ sub-samples using SedgewickRafter chambers and Hensen-Stempell pipette. At least three sub-samples were counted, containing at least 80 individuals within each sub-sample (Bottrell et al., 1976). These sub-samples were then summed, and the organism's density for the total sample volume was then estimated and expressed in individuals. $\mathrm{m}^{-3}$.

Biovolume calculation for rotifers was determined according to Ruttner-Kolisko (1977), and the biovolume values were converted to wet weights. Assuming that $10^{6} \mu \mathrm{m}^{3}$ corresponds to $1 \mu \mathrm{g}$ of wet weight (Bottrell et al., 1976), the dry weight was estimated as $10 \%$ of wet weight (Pace and Orcutt Junior, 1981). The cladoceran and copepods biomass were estimated through calculated length-weight relationships (from weighing in a micro-analytical balance of $10^{-7} \mathrm{~g}$ ) (Mc Cauley, 1984; Wetzel and Likens, 2000).

The organisms' length was obtained under optical microscope, using an objective with micrometer reticle, considering (i) for the rotifers, the distance between the superior and inferior margin of carapace, without spines; (ii) for the cladocerans, the distance from the head until the end of the carapace, without the helmet and spine; and (iii) for the copepods, the distance from the head until the genital segment. These measures were taken from at least 30 individuals of each species. The individuals were classified as: smaller-sized, for those belonging to size class lesser than $300 \mu \mathrm{m}$; intermediate-sized, for those belonging to size class ranging from 301 to $600 \mu \mathrm{m}$; and larger-sized, for those individuals belonging to size class greater than $601 \mu \mathrm{m}$.

According to Bottrell et al. (1976) and Dumont et al. (1975), the weight differences between organisms preserved in formaldehyde, as used in our study, and non-preserved organisms are negligible or showed a little influence on the biomass results. Thus, mathematical corrections for the obtained weight results were not performed.

All individuals of fishes were identified, enumerated, weighed (g) and classified according to Britski et al. (1999). Voucher specimens were deposited in the Ichthyological Collection of Nucleus of Research in Limnology, Ichthyology and Aquaculture (Nupelia). In order to indicate fishes species potentially consumers of zooplankton, we consulted bibliography for tropical fishes (Casatti et al., 2003; Cassemiro et al., 2002; Crippa et al., 2009; Russo and Hahn 2006; Pelicice and Agostinho, 2006; Santana-Porto and Andrian, 2009) and a list available in http://www.fishbase. org/.

\subsection{Data analyses}

Mann-Whitney tests were realized in order to verify differences in limnological features of the water between seasons.

Principal Component Analysis (PCA) was used to summarize the relationship between samples locales and limnological features. Data were standardized through a correlation matrix.

Linear regression analyses were carried out, separately, to verify as fish density and chlorophyll-a concentration are associated with aggregate community properties (density and biomass) and with percentage of size classes on the community structure. Values of fish density, chlorophyll-a concentration, zooplankton biomass and density were $\log$-transformed to minimize data variability and assist the visualization of the results. The regression assumptions were tested through residual visualization.

The significant level adopted in the analysis was 0.05 , meaning that $p$-values lower than 0.05 , the relationships recorded are rare under a normal probability distribution. Even the results obtained arose from an empirical study with sampling 
effort limited to eight lakes, hence lacking any manipulation of the descriptor variables and preventing a cause-effect approach.

\section{Results}

\subsection{Limnology}

Electric conductivity, dissolved oxygen and $\mathrm{pH}$ were significantly higher in the dry season, while ammonium and phosphate were higher in the rainy season (Table 2). In the dry season, turbidity, nitrate, nitrite and phosphate had most loadings for axis 1 (PCA), while chlorophyll- $a$ and dissolved oxygen were most important for axis 2 (Figure 2a). During rainy season, chlorophyll-a, $\mathrm{pH}$ and phosphate forms characterized the axis 1 , while turbidity and total alkalinity were important to axis 2 (Figure $2 \mathrm{~b}$ ). In both seasons, the locales $\mathrm{E}$, $\mathrm{H}, \mathrm{C}$ and F (Genipapo, Pousada das Garças, Clara and Osmar Lakes, respectively) had lower levels of nutrients and chlorophyll- $a$ concentration, while D (Jacaré lake) showed higher levels of nutrients and chlorophyll-a concentration.

\subsection{Zooplankton}

Zooplanktonic community was represented by 101 species in the dry and 103 species in rainy season. During dry seasons, Lecane proiecta Hauer, 1956, Bosmina hagmanni Stingelin, 1904, and Notodiaptomus iheringi Wright, 1935, were the species most important, of each group (rotifer, cladoceran and copepod), in abundance and biomass. While in rainy season the species most important, of each group, were: Asplanchna sp., Diaphanosoma spinulosum Herbst, 1967, and Notodiaptomus amazonicus Wright, 1935.
Zooplankton abundance ranged from 8,728 ind. $\mathrm{m}^{-3}$ to $4,622,461$ ind. $\mathrm{m}^{-3}$. In dry season, a greater number of individuals was observed in the Osmar (F) $\left(420,654\right.$ ind. $\left.\mathrm{m}^{-3}\right)$ and Genipapo lakes (E) $\left(456,977\right.$ ind. $\mathrm{m}^{-3}$ ) (Figure 3a). On the other hand, in the rainy season, the highest abundance was registered in Capivara Lake (A) $\left(4,622,461\right.$ ind. $\left.\mathrm{m}^{-3}\right)$ (Figure 3b).

Zooplankton biomass varied between 7,128 $\mu \mathrm{g}$.dw. $\mathrm{m}^{-3}$ and 265,740 $\mu \mathrm{g}$.dw. $\mathrm{m}^{-3}$. As observed for the density, the highest value of biomass was recorded in rainy season at Capivara Lake (A) $\left(265,740 \mu \mathrm{g} . \mathrm{dw} \mathrm{m}^{-3}\right)$, and in the dry season the highest values was in Osmar Lake (F) $\left(252,993 \mu \mathrm{g} . \mathrm{dw} \cdot \mathrm{m}^{-3}\right)$ (Figure 3b). Zooplankton density and biomass presented a positive association during both dry $(\mathrm{p}=0.0154)$ and rainy seasons ( $\mathrm{p}=0.0001)$.

The individuals' sizes in the lakes ranged from 70 to $1,260 \mu \mathrm{m}$. The distribution pattern of the size classes within each environment was distinct between the seasons (Figures 4 and 5). In general, the individuals of intermediate size $(300-600 \mu \mathrm{m})$ were more abundant in the dry season (Figure $4 \mathrm{~b}$ ), whereas smaller-sized individuals $(<300 \mu \mathrm{m})$ presented a greater numerical contribution to the community in the rainy season (Figure 5b). Considering the overall biomass, larger-sized organisms $(>600 \mu \mathrm{m})$ were dominant in the dry season (Figure 4c).

\subsection{Fishes}

Thirty-four species of fish were recorded, but only eight of these (Table 3) ever had individual's zooplankton as food item. The density of fishes ranged from four (Capivara - A) to 38,624

Table 2. Limnological features variation in the dry and rainy seasons in eight shallow lakes from Upper Paraná Floodplain. *Significant differences $(\mathrm{p}<0.05)$ between seasons (Mann-Whitney test).

\begin{tabular}{|c|c|c|c|c|}
\hline & \multicolumn{2}{|c|}{ Dry } & \multicolumn{2}{|c|}{ Rainy } \\
\hline & Minimum & Maximum & Minimum & Maximum \\
\hline $\mathrm{pH}^{*}$ & 6.0 & 6.7 & 5.7 & 6.4 \\
\hline Electric conductivity $\left(\mu \mathrm{S} . \mathrm{cm}^{-1}\right)^{*}$ & 23.9 & 107.5 & 20.3 & 62.7 \\
\hline Total alkalinity (mEq. $\left.\mathrm{L}^{-1}\right)$ & 75.5 & 877.1 & 107.7 & 631.2 \\
\hline Turbidity (NTU) & 3.4 & 217.0 & 3.0 & 36.3 \\
\hline Dissolved Oxygen $\left(m g \cdot \mathrm{L}^{-1}\right)^{*}$ & 3.5 & 7.2 & 2.1 & 4.9 \\
\hline Chlorophyll-a ( $\left.\mu g . L^{-1}\right)$ & 1.1 & 143.3 & 3.9 & 44.6 \\
\hline Nitrate $\left(\mu \mathrm{g} \cdot \mathrm{L}^{-1}\right)$ & 0.1 & 205.6 & 7.8 & 124.3 \\
\hline Nitrite $\left(\mu g . L^{-1}\right)$ & 1.0 & 2.8 & 0.7 & 2.6 \\
\hline Ammonium $\left(\mu \mathrm{g} \cdot \mathrm{L}^{-1}\right)^{*}$ & 0.1 & 37.0 & 3.4 & 101.0 \\
\hline Phosphate $\left(\mu \mathrm{g} \cdot \mathrm{L}^{-1}\right)^{*}$ & 0.1 & 20.3 & 10.3 & 53.4 \\
\hline Dissolved phosphorus $\left(\mu \mathrm{g} \cdot \mathrm{L}^{-1}\right)$ & 2.0 & 44.7 & 3.6 & 18.8 \\
\hline
\end{tabular}



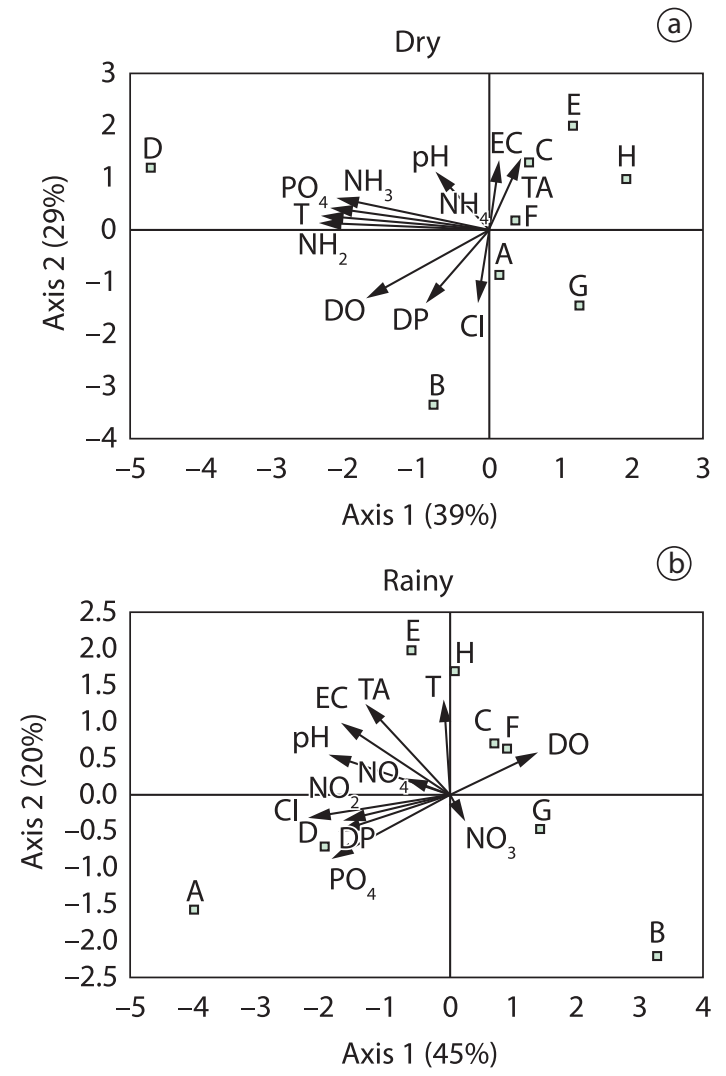

Figure 2. Biplot of the Principal component analysis. Characterization of the locales sampled as the physical and chemical features of water. a) Dry season (August 2000); and b) Rainy season (February 2001); Locales: Capivara-A, Aurélio-B, Clara-C, Jacaré-D, Genipapo-E, Osmar-F, Traíra-G and Pousada-H. EC - Electric Conductivity; TA - Total Alkalinity; T - Turbidity; DO - Dissolved Oxygen; Cl - Chlorophyll-a; $\mathrm{NH}_{3}$ - Nitrate; $\mathrm{NH}_{2}$ - Nitrite; $\mathrm{NH}_{4}-$ Ammonium; $\mathrm{PO}_{4}$ - Phosphate; $\mathrm{PD}$ - Dissolved phosphorus.

(Pousada Garças - H) individuals (CPUE) during dry (Figure 4a), while ranged 56 (Genipapo - E) to 3,749 (Pousada Garças - H) individuals (CPUE) in rainy season (Figure 5a).

\subsection{Relationship of density and biomass of the zooplankton community with the chlorophyll-a concentration and fish density}

Density and biomass of the zooplankton community did not show significant relationship with chlorophyll- $a$ concentration in the dry season (Figure $6 \mathrm{a}$ and $\mathrm{b}$ ). Otherwise, they were positively associated to chlorophyll- $a$ concentration during rainy season (Figure $6 \mathrm{c}$ and $\mathrm{d}$ ), suggesting that the increase in resource amount promotes a significant increase in the aggregate properties of the zooplankton community (biomass and density).


Biomassa $\square$ Abundance

Figure 3. Biomass and abundance of the zooplankton community in the lakes (Capivara-A, Aurélio-B, Clara-C, Jacaré-D, Genipapo-E, Osmar-F, Traíra-G and Pousada-H) during the dry and rainy seasons (August-2000 and February-2001, respectively).

Community abundance and biomass were positively associated to fish density during the dry season (Figure $7 \mathrm{a}$ and b), although only the abundance has been significant relationship, and were negatively associated in the rainy season (Figure $7 \mathrm{c}$ and $\mathrm{d}$ ).

\subsection{Relationship between size structure of the zooplankton and fishes}

The size structure of the community did not show significant relationship with chlorophyll-a concentration $(p>0.05)$, but it was associated to the increase in fish density during the dry season. The percentage of individuals with intermediate sizes, in both biomass and density, was positively related to the fish density $\left(\mathrm{R}^{2}=0.78\right.$ for biomass, $\mathrm{p}<0.001 ; \mathrm{R}^{2}=0.58$ for density, $\left.\mathrm{p}=0.02\right)$, 

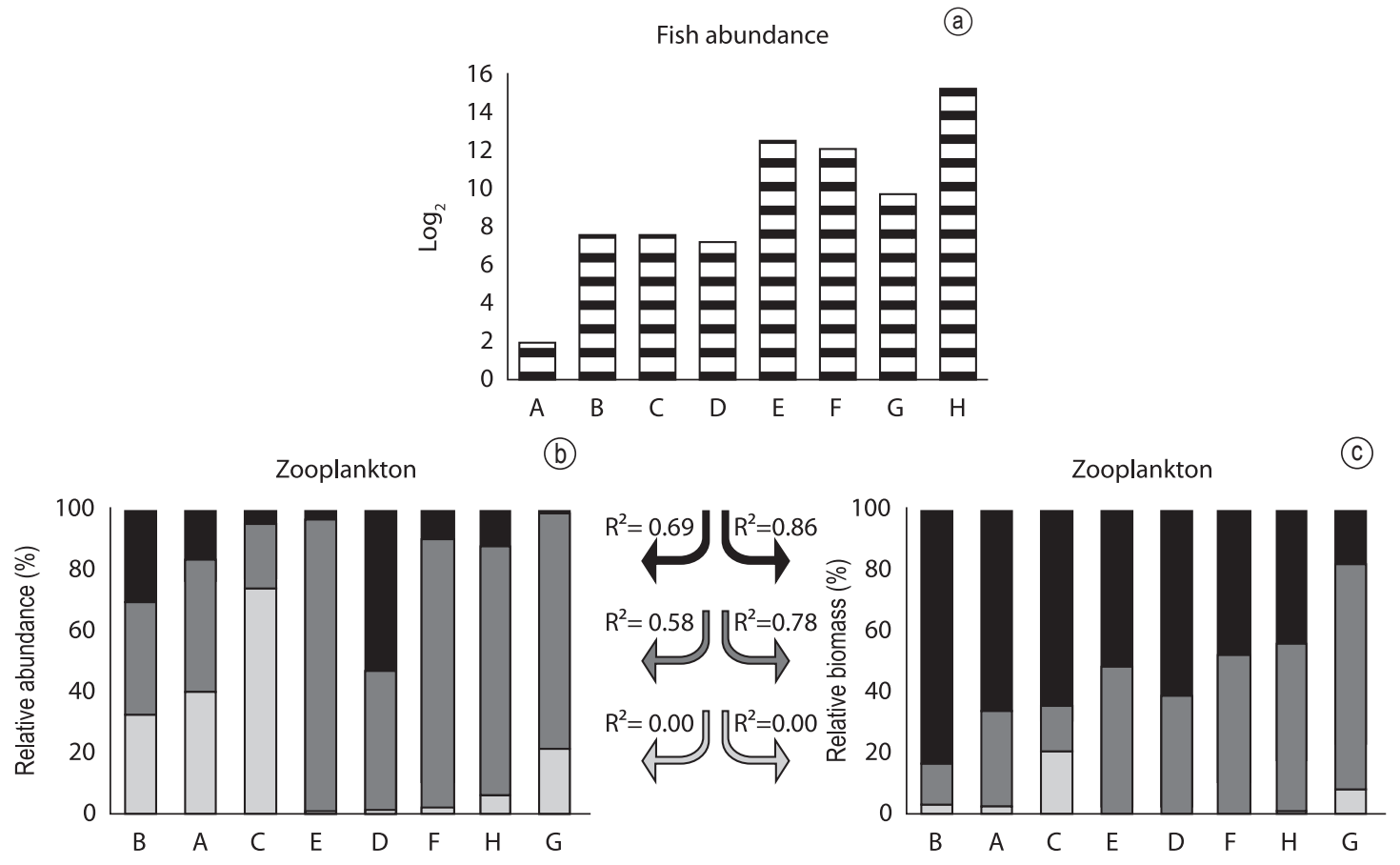

Figure 4. Representation of the simple regression analyses between zooplankton and fish abundance obtained in the lakes during the dry season (August-2000). a) Density of fishes (CPUE); b) Relative abundance; and c) Relative biomass. $\mathrm{R}^{2}$ - coefficient of determination resultant of linear regression. Black, gray and dotted percents are $>600$, 301-600 and $<300$ size classes, respectively.

Fish abundance
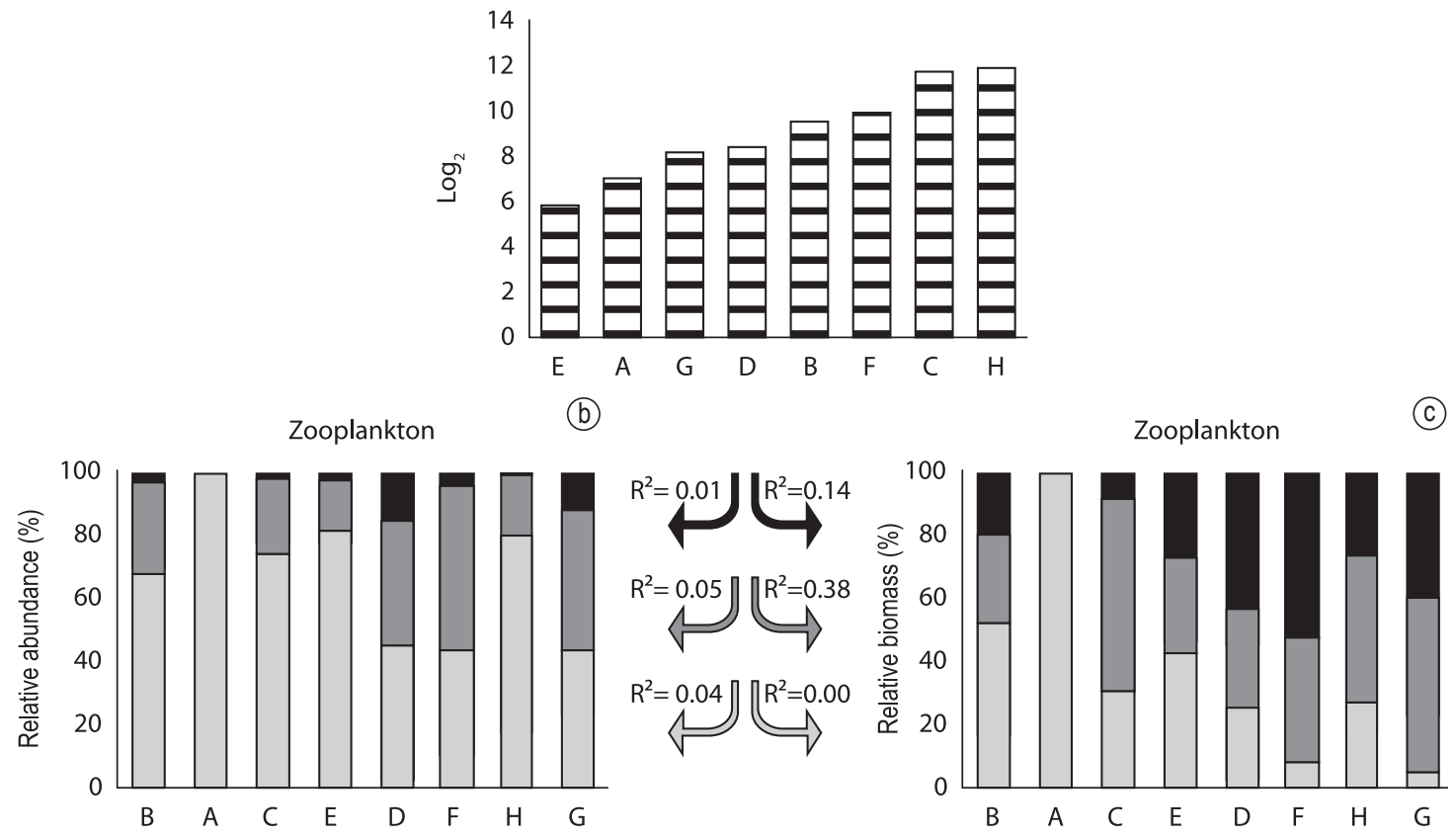

Figure 5. Representation of the simple regression analyses between zooplankton and fish abundance obtained in the lakes during the rainy season (February-2001). a) Density of fishes (CPUE); b) Relative abundance; and c) Relative biomass. $\mathrm{R}^{2}$ - coefficient of determination resultant of linear regression. Black, gray and dotted percents are $>600$, 301-600 and $<300$ size classes, respectively. 
Table 3. Zooplanktivorous fishes species sampled lakes from Upper Paraná Floodplain during dry (September 2000) and rainy seasons (March 2001). The fonts are scientific records of zooplankton as food item of fish species.

\begin{tabular}{ll}
\hline \multicolumn{1}{c}{ Species } & \multicolumn{1}{c}{ Font } \\
\hline Astyanax altiparanae Garutti and Britski, 2000 & Casatti et al., 2003; Cassemiro et al., 2002 \\
Aphyocharax anisitsi Eigenmann and Kennedy, 1903 & Crippa et al., 2009; Russo and Hahn 2006; \\
& Santana-Porto and Andrian, 2009; fishbase \\
Bryconamericus stramineus Eigenmann, 1908 & Crippa et al., 2009; Santana-Porto and Andrian 2009. \\
Hyphessobrycon eques Steindachner, 1882 & Casatti et al., 2003; Crippa et al., 2009; \\
& Pelicice and Agostinho, 2006; fishbase \\
Hemigrammus marginatus Ellis, 1911 & Casatti et al., 2003; Pelicice and Agostinho, 2006; fishbase \\
Moenkhausia aff. Intermedia Eigenmann, 1908 & Santana-Porto and Andrian, 2009; fishbase \\
M.aff.sanctaefilomenae Steindachner, 1907 & Crippa et al., 2009; fishbase \\
Serrapinnus notomelas Eigenmann, 1915 & Pelicice and Agostinho, 2006; \\
& Santana-Porto and Andrian, 2009; fishbase \\
\hline
\end{tabular}
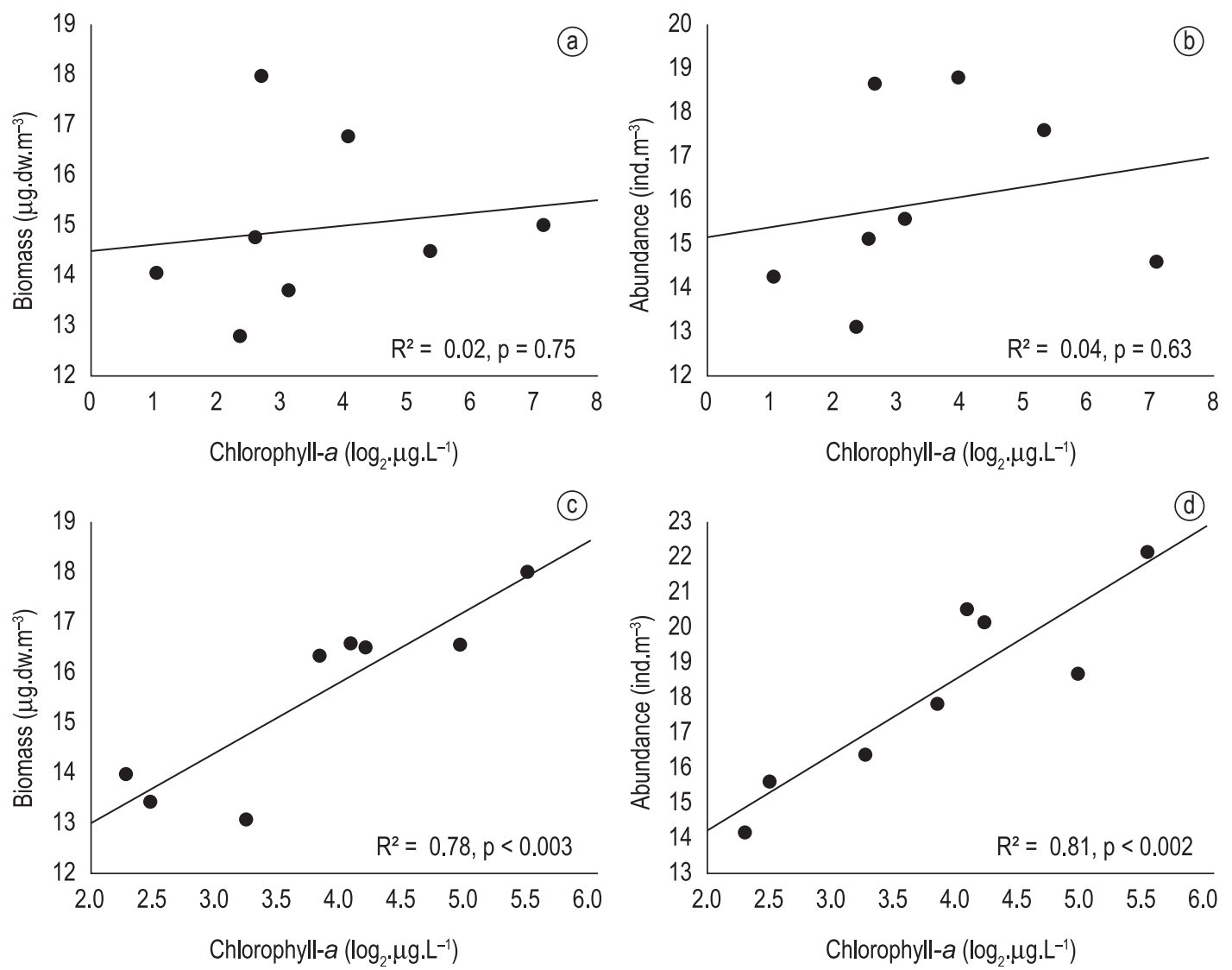

Figure 6. Association of the total density and biomass zooplanktonic with chlorophyll- $a$ concentration in the lakes during the dry ( $\mathrm{a}$ and $\mathrm{b})$ and rainy $(\mathrm{c}$ and $\mathrm{d})$ seasons.

indicating a numerical and mass increase of this size class with fish density (Figure 4). The percentage of larger-sized individuals, in both biomass $\left(\mathrm{R}^{2}=0.86\right.$, $\mathrm{p}<0.001)$ and density $\left(\mathrm{R}^{2}=0.69, \mathrm{p}=0.02\right)$ was negatively associated to the fish density, reflecting a decrease of this size class with the increase of fish in the environment (Figure 4).

During rainy season, the regressions were not significant, indicating that the proportion of community size classes was not associated to the fish densities (Figure 5).

\section{Discussion}

The present study evidenced the positive significant association of the density and biomass of zooplankton with fish density, as seen during the dry period (Figure $7 \mathrm{a}$ and $\mathrm{b}$ ). This could 


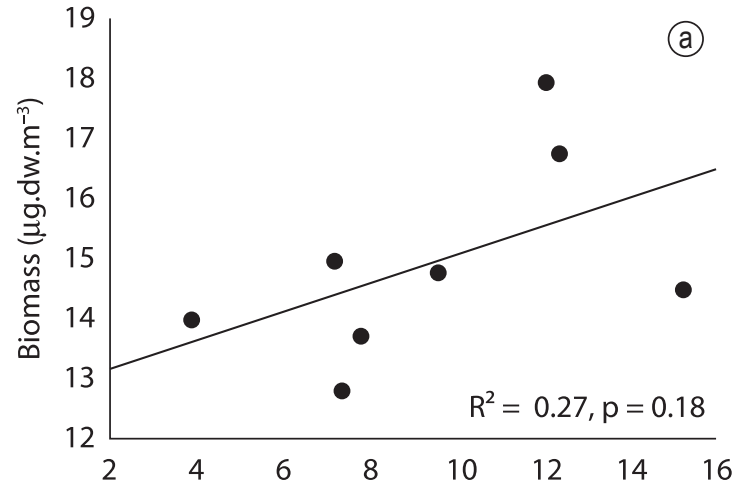

Fish abundance $\left(\log _{2}\right.$. ind $\left..100 . \mathrm{m}^{-2}\right)$

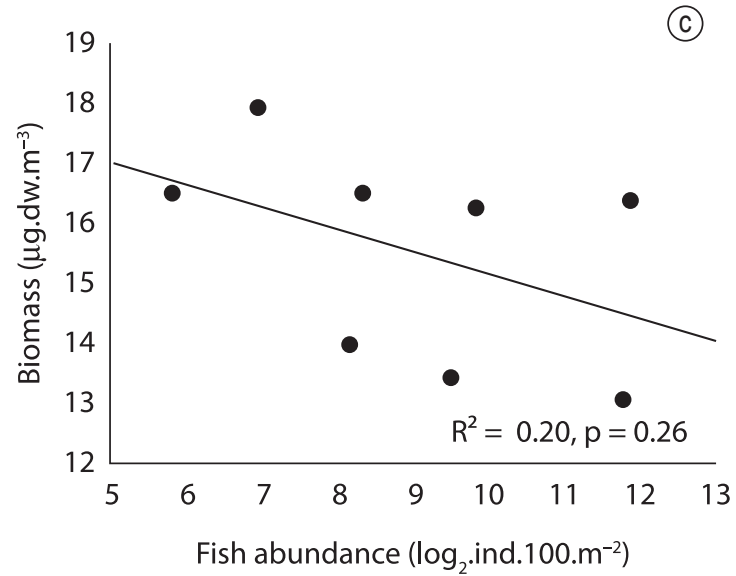

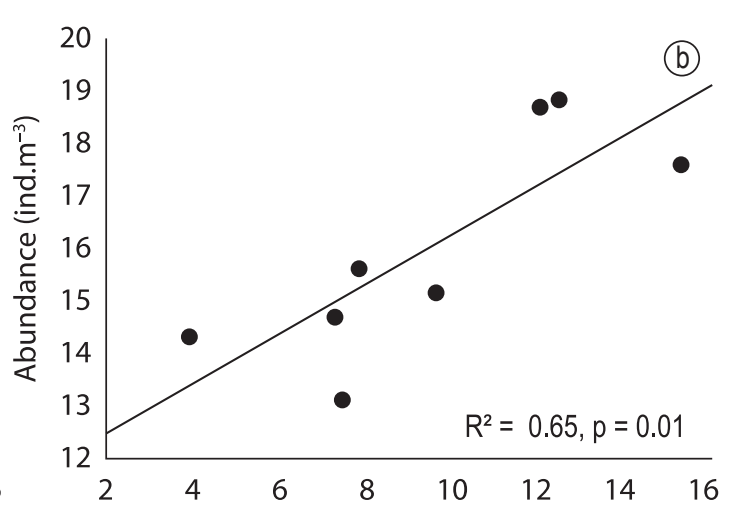

Fish abundance $\left(\log _{2}\right.$.ind.100. $\left.\mathrm{m}^{-2}\right)$

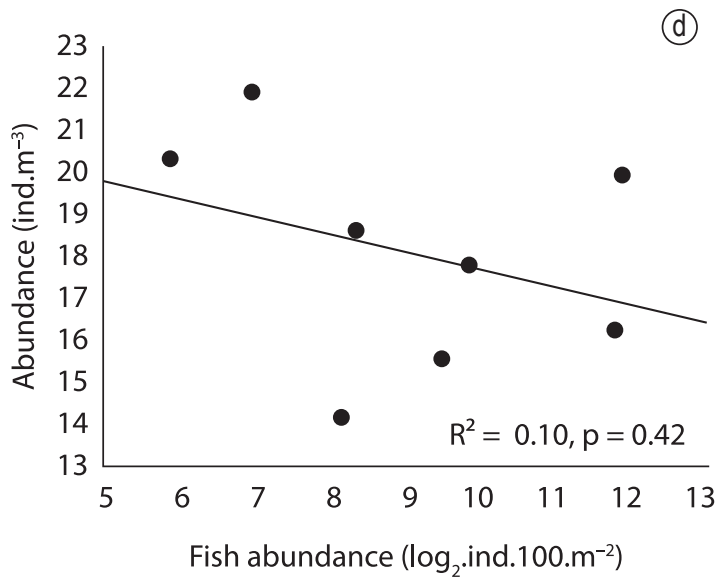

Figure 7. Association of the total density and biomass zooplanktonic with fish density (CPUE) in the lakes during the dry ( $a$ and b) and rainy (c and d) seasons.

disguise the predation effect on the individuals, once this effect was remarkable only in the class of larger size (Figure 4), consequently decreasing the density and biomass larger-sized individuals and increasing density and biomass intermediate-sized individuals. The predation reduces the competitive effect between different size classes, promoting the development of populations with small-sized individuals (Wang et al., 2007) and corroborating the predation effect on the size-efficiency hypothesis (Brooks and Dodson, 1965; Dodson, 1974). This implicates a direct and negative effect of the predation on larger-sized individuals, as well as indirect and positive effect on the small-sized individuals. Several studies have registered the numerical reduction of larger-sized zooplankton individuals, mainly with sizes greater than $500 \mu \mathrm{m}$, as a function of a predation effect (Bramm et al., 2009; Manca et al., 2008; Masson et al., 2004; Rettig, 2003).

The positive association between the density and biomass of zooplankton with the fish density may also suggest that the predator density does not exert a predation pressure on the community; but other effect would act positively on the structure of these two communities, promoting a concordance between them, or that the predation effect is not enough to negatively influence the structure of the zooplankton community. Thus, the explanation for the increase in zooplankton density and biomass total would be the direct influence of autotrophic production, or an indirect influence, as for fish excretion, that would also influence the same production (Attayde and Hansson, 2001).

On the other hand, in the rainy period, when we did not verify a significant and direct relationship between the density of fish and the size classes of the zooplankton community (Figure 5), the biomass and density of the community were also associated with local productivity, represented by the chlorophyll-a concentration (Figure $6 \mathrm{c}$ and $\mathrm{d}$ ). This association evidenced that the increase in resource availability favored increment of individuals. The productivity has been reported as the most important factor regulating the zooplankton biomass (because it reflects the increase in resource availability), but 
it also has been associated to the size structure, i.e., more productive environments will present a predominance of small-sized individuals, and the inverse will be observed in less productive environments (Masson et al., 2004). Thus, in the rainy period a bottom-up effect may be more important than top-down one, on the size structure of the zooplankton community.

Masson et al. (2004) considered bottom-up and top-down processes as complementary strengths on the zooplankton structure and may act temporally on the community properties, in this case, the biomass and size structure. Similarly, Winder et al. (2003) suggest that the combination of predation and resource limitation defines the temporal variability of zooplankton size structure. Our results only indicated evidence to top-down effect in the dry period, mainly affecting the size structure of the community, in which there was a removal of larger-sized individuals.

Under the spatial perspective (among lakes), the size structure of the zooplankton community has been related to physical, chemical and biotic aspects (Cottenie et al., 2001; Masson et al., 2004; Drenner et al., 2009). The obtained results corroborated previous studies and indicate that even in tropical environments, in which zooplankton communities are compounded by small-sized species (Fernando, 1994), the size structure of the zooplankton community may be related to top-down effect. Drenner et al. (2009) ascribed the differences found in the zooplankton size structure to the presence of fish, since the greater efficiency of predation on adult individuals from larger-sized species prevent the reproduction and, in consequence, the recruitment of new individuals with larger-size in the population. Productive environments, with higher fish densities, produces a higher selection pressure on the larger-sized individuals of zooplankton, while a lower density of fish would decrease the predation effect, allowing a greater survival of these larger-sized individuals (Cottenie et al., 2001).

Small zooplankton generally ate fine particles (1-5 $\mu \mathrm{m})$, whereas larger zooplankton generally consumed larger particles (Gliwicz, 1969). Large populations of smaller-sized individuals are related to a greater efficiency of these organisms in the assimilation of smaller organisms, as bacteria, nanophytoplankton and small planktonic protozoan, suggesting a greater importance of the "microbial loop" in the energy transfer. On the other hand, when there is a numerical predominance of larger-sized individuals, it can mean that producer organisms with larger size are present in the environment, as filamentous algae, suggesting that the base of the food chain is herbivory. In this way, the seasonality differences of our results would enable to indicate other scientific investigation process, where the climatic periods would modify the energy transfer process; an alternative to support this hypothesis is the evaluation of the nano- and micro-planktonic communities. It is clear that the evaluation of these hypotheses depends on a better understanding of the relationship between zooplankton size and food size.

The results add information about biotic mechanisms (which influence the zooplankton size structure in temperate lakes, where the size gradient among the species is noticeable) that may also be extrapolated to tropical environments, which are compounded by zooplankton communities with a mean size inferior to that in temperate regions. In summary, we verified that the main hypothesis of this study was partially confirmed because it was supported only one sampling season; however this suggests that different mechanisms act on the size structure of the zooplankton community between the analyzed periods.

\section{Acknowledgements}

We thank the Nupélia's laboratories of Limnology and Ichthyology for their assistance with the physical and chemical variables of water and provision of estimates of fish, respectively. We thank M.Sc. Juliana Déo Dias for suggestions. This study was supported by the "Long-Term Ecological Research" (LTER) program of CNPq. Claudia Costa Bonecker has been supported by CNPq productivity fellowships. Nadson Ressyé Simóes had Capes scholarship.

\section{References}

ATTAYDE, J. and HANSSON, L. 2001. The relative importance of fish predation and excretion effects on planktonic communities. Limnology and Oceanography, vol. 46, p. 1001-1012. http://dx.doi. org/10.4319/lo.2001.46.5.1001

BOGDAN, K. and GILBERT, J. 1984. Body size and food size in freshwater zooplankton. Proceedings of the National Academy of Sciences (USA), vol. 81, p. 6427-6431. http://dx.doi.org/10.1073/ pnas.81.20.6427

BERGAMIN, H., REIS, BF. and ZAGATTO, EAG. 1978. A new device for improving sensitivity and stabilization in flow injection analysis. Analytica Chimica Acta, vol. 97, p. 63-70. 
BOTTRELL, HH., DUNCAN, A., GLIWICZ, Z., GRYGIEREK, E, HERZIG, A., HILLBRICHTILLKOWSKA, A., KURUASAWA, H., LARSSON, P. and WEGLENSKA, T. 1976. A review of some problems in zooplankton production studies. Norwegian Journal Zoology, vol. 24, p. 419-456.

BRAMM, ME., LASSEN, MK., LIBORIUSSEN, L., RICHARDSON, K., VENTURA, M. and JEPPESEN E. 2009. The role of light for fishzooplankton-phytoplankton interactions during winter in shallow lakes - a climate change perspective. Freshwater Biology, vol. 54, p. 1093-1109. http:// dx.doi.org/10.1111/j.1365-2427.2008.02156.x

BRITSKI, HA., SILIMON KZ. and LOPES, BS. 1999. Peixes do Pantanal: manual de identificação. Corumbá: Embrapa. 184 p.

BROOKS, J. and DODSON, S. 1965. Predation, body size, and composition of plankton. Science, vol. 150, p. 28-35. PMid:17829740. http://dx.doi. org/10.1126/science.150.3692.28

CHASE, J., ABRAMS, P., GROVER, J., DIEHL, S., CHESSON, P., HOLT, R., RICHARDS, S., NISBET, R. and CASE, T. 2002. The interaction between predation and competition: a review and synthesis. Ecology Letters, vol. 5, p. 302-315. http:// dx.doi.org/10.1046/j.1461-0248.2002.00315.x

CARMOUZE, J. 1994. Metabolismos dos ecossistemas aquáticos: fundamentos teóricos, métodos de estudo e análises quimicas. São Paulo: Edgard Blucher, Fapesp. 253 p.

CASATTI, L., MENDES, HF. and FERREIRA, KM. 2003. Aquatic macrophytes as feeding site for small fishes in the Rosana reservoir, Paranapanema river, southeastern Brazil. Brazilian Journal Biology, vol. 63, no. 2, p. 213-222. http://dx.doi.org/10.1590/ S1519-69842003000200006

CASSEMIRO, FAZ., HAHN, NS. and FUGI, R. 2002. Avaliação da dieta de Astyanax altiparanae Garutti \& Britski, 2000 (Osteichthyes, Tetragonopterinae) antes e após a formação do reservatório de Salto Caxias, Estado do Paraná, Brasil. Acta Scientiarum Biological Sciences, vol. 24, no. 2, p. 419-425.

CRIPPA, FAZ., HAHN, NS. and FUGI, R. 2009. Food resource used by small-sized fish macrophyte patches in ponds of the upper Paraná river floodplain. Acta Scientiarum Biological Sciences, vol. 31, no. 2, p. 119-125.

COTTENiE, K., NUYTTEN, N., MiCHELS, E. and DE MEESTER, L. 2001. Zooplankton community structure and environmental conditions in a set of interconnected ponds. Hydrobiologia, vol. 442, p. 339-350. http://dx.doi. org/10.1023/A:1017505619088

DECLERCK, S., VANDERSTUKKEN, M., PALS, A., MUYLAERT, K. and DE MEESTER, L. 2007. Plankton biodiversity along a gradient of productivity and its mediation by macrophytes. Ecology, vol. 88, 2199-2210. PMid:17918398. http://dx.doi. org/10.1890/07-0048.1

DODSON, S. 1974. Zooplankton competition and predation: an experimental test of the sizeefficiency hypothesis. Ecology, vol. 55, p. 605-613. http://dx.doi.org/10.2307/1935150

DRENNER, S., DODSON, S., DRENNER, R. and PINDER III, J. 2009. Crustacean zooplankton community structure in temporary and permanent grassland ponds. Hydrobiologia, vol. 632, p. 225-233. http://dx.doi.org/10.1007/s10750-009-9843-4

DUMONT, HJ., VAN DE VELDE, I. and DUMONT, S. 1975. Dry weight estimate of biomass in a selection of cladocera, copepoda and rotifera from plankton, periphyton and benthos of continental waters. Oecologia, vol. 1, no. 19, p. 75-97.

ELMOOR-LOUREIRO, LMA. 2005. As patas dos cladóceros: descrição e importância taxonômica. Limnotemas, vol. 5, p. 1-22.

FERNANDO, C. 1994. Zooplankton, fish and fisheries in tropical freshwaters. Hydrobiologia, vol. 272, p. 105-123. http://dx.doi.org/10.1007/BF00006516

GLIWICZ, Z. 1969. Share of algae, bacteria and trypton in the food of the pelagic zooplankton of lakes with various trophic characteristics. Bulletin Academia Polonia Sciences, vol. 17, p. 159-165.

GOLTERMAN, H., CLYMNO, R. and OHNSTAD, M. 1978. Methods for Physical, and Chemical Analysis for Fresh Waters: IBP Handbook. Oxford: Blackwell Scientific Publications. 213 p.

HART, RC. and BYCHEK, EA. 2011. Body size in freshwater planktonic crustaceans: an overview of extrinsic determinants and modifying influences of biotic interactions. Hydrobiologia, vol. 668, p. 61-108. http://dx.doi.org/10.1007/s10750-0100400-y

HAMBRIGHT, KD. 2008. Long-term zooplankton body size and species changes in a subtropical lake: implications for lake management. Archive of Hydrobiology, vol. 173, p. 1-13.

HORN, W. 2003. Long-term development of the crustacean plankton in the Saidenbach Reservoir (Germany) - changes, causes, consequences. Hydrobiologia, vol. 405, p. 185-192. http://dx.doi. org/10.1023/B:HYDR.0000008518.30455.5e

LAMPERT, W. and SOMMER, U. 1997. Limnoecology: the ecology of lakes and streams. 2th ed. Oxford: University Press. 324 p.

MACKERETH, F., HERON, J. and TALLING, J. 1978. Water analysis: some revised methods for limnologists. Kendal: Freshwater Biological Association, Titus Wilson \& Sons Ltda. 117 p.

MANCA, M., VIJVERBERG, J., POLISHCHUK, L. and VONONOV, D. 2008. Daphnia body size and population dynamics under predation by invertebrate 
and fish predators in Lago Maggiore: an approach based on contribution analysis. Journal of limnology, vol. 67, p. 15-21.

MASSON, S., PINEL-ALLOUL, B. and DUTILLEUL, P. 2004. Statial heterogeneity of zooplankton biomass and size structure in southern Québec lakes: variation amosg lakes and within lake among epi-, meta- and hypolimnion strata. Journal of Plankton Research, vol. 26, p. 1441-1458. http://dx.doi.org/10.1093/ plankt/fbh138

MC CAULEY, E. 1984. The estimation of the abundance and biomass of zooplankton in samples. In DOWNING, JA. and RIGLER, FH., orgs. A manual on methods for the assessment of secondary productivity in fresh waters. 2th ed. Oxford: Blackwell Scientific. p. 228-265.

PACE, ML. and ORCUTT JUNIOR, JD. 1981. The relative importance of protozoans, rotifers and crustaceans in a freshwater zooplankton community. Limnolology and oceanography, vol. 26, p. 822-830.

PETERS, RH. 1983. The Ecological Implications of Body Size. Cambridge: Cambridge University Press, 328 p.

PELICICE, FM. and AGOSTINHO, AA. 2006. Feeding ecology of fishes associated with Egeria spp. patches in a tropical reservoir, Brazil. Ecology of Freshwater Fish, vol. 15, p. 10-19. http://dx.doi.org/10.1111/j.16000633.2005.00121.x

RETTIG, J. 2003. Zooplankton responses to predation by larval bluegill: an enclosure experiment. Freshwater Biology, vol. 48, p. 636-648. http://dx.doi. org/10.1046/j.1365-2427.2003.01035.x
RUTTNER-KOLISKO, A. 1977. Suggestions for biomass calculations of plankton rotifers. Archive of Hydrobiology, vol. 8, p. 71-76.

RUSSO, MR and HAHN, NS. 2006. Importance of zooplankton in the diet of a small fish in lagoons of the upper Paraná River floodplain, Brazil. Acta Limnologica Brasiliensia, vol. 18, no. 4, p. 357-366.

SANTANA-PORTO, EA. and ANDRIAN, IF. 2009. Trophic organization the ichthyofauna of two semilentic environments in a flood plain on the upper Paraná River, Brazil. Acta Limnologica Brasiliensia, vol. 21, no. 3, p. 359-366.

THACKERAY, SJ. 2007. Crustacean zooplankton species richness and productivity: to what extent do the conclusions depend upon the choice of metrics? Oikos, vol. 116, 614-628. http://dx.doi.org/10.1111/ j.0030-1299.2007.15513.x

WANG, S., PING, X., WU, S. and HAIJUN, W. 2007. Crustacean zooplankton size structure in aquaculture lakes: is larger size structure always associated with higher grazing pressure? Hydrobiologia, vol. 575, p. 203-209. http://dx.doi.org/10.1007/s10750006-0394-7

WETZEL, RG. and LIKENS, GE. 2000. Limnological analyses. New York: Springer-Verlag. 429 p.

WINDER, M., BURGI, H. and SPAAK, P. 2003. Mechanisms regulating zooplankton populations in a high-mountain lake. Freshwater Biology, vol. 48, p. 795-809. http://dx.doi.org/10.1046/j.13652427.2003.01054.x 